\section{超高層免震建物の地震動観測記 録に基づく免震層および上部構 造の剛性の評価}

\section{EVALUATION OF STIFFNESS OF BASE-ISOLATION LAYER AND SUPER- STRUCTURE OF HIGH-RISE BASE- ISOLATED BUILDING BASED ON SEISMIC OBSERVATION RECORDING}

$\begin{array}{ll}\text { 中井亜里沙— }-11 & \text { 佐藤大樹 }-* 2 \\ \text { 村上智一 }-3 & \text { 笠井和彦 }-24\end{array}$

キーワード

超高層免震建物，地震応答観測記録，履歴曲線，剛性

Keywords:

High-rise seismic isolated building, Earthquake response observation, Hysteresis curve, Stiffness

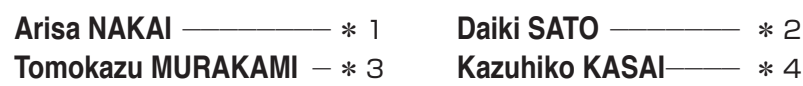

The purpose of this paper is to evaluate stiffness of a base-isolation layer and a super-structure of high-rise seismic isolated building from the earthquake response observation records with different amplitude levels. As a result, the stiffness of the base-isolation layer based on observation records was close to the design value. As the amplitude increased, the stiffness of the super-structure reduced - confirming the amplitude dependence of the super-structure.
1. はじめに

1995 年に発生した阪神・淡路大震災以降，免震建物の優れた耐震 性能が評価され，その需要が高まった。さらに，2011 年に発生した 東日本大震災においても, 震源に近い三陸地方から関東地方を含む 広範囲にわたって継続時間の長い長周期地震動を受けたにもかかわ らず, 建物としての機能を損なうような被害はなかったことから, そ の後も免震構造の採用が増え, 2014 年末までに約 4000 棟もの免震建 物が建設されている ${ }^{1)}$ 。初期は建物の機能を守る必要が高い建物や防 災拠点, 病院などに免震建物が採用される例が多く, 中低層建物を中 心に建設されていたが，近年においては集合住宅や事務所ビルなど にも, 免震構造が積極的に採用され, 中低層建物のみでなく超高層建 物への適用も拡大しており ${ }^{1)}$, 今後もさらに増加していくことが予想 される。低層の免震建物の場合は, 免震層にアイソレーターや減衰装 置を設置することで上部構造を相対的に剛と仮定することができる が, 上部構造が高層化して長周期化することで, 免震層に対する上部 構造の剛性が相対的に低くなるため前述の仮定は成立しなくなる。

免震建物の実挙動を知ることは重要であるが，観測記録に基づく 超高層免震建物の応答を報告した例は僅かである例えば 2) 11)。地震応 答観測記録に基づく報告としては, 天埜らによる建設中の $\mathrm{RC}$ 造免震 建物を対象とした建設時における振動特性の変化についての報告 ${ }^{2)}$ や, 松田, 笠井による東北地方太平洋地震における観測記録を用いた 超高層免震建物の動的挙動に関する報告 $)^{3}$ などがある。上述したよう に, 超高層免震建物では上部構造の剛性評価が重要となるが, 観測記 録に基づく報告例は少なく2),11), 知見の蓄積が必要である。限定され た層の応答を用いた剛性評価として，加速度線形補間によるものが

ある ${ }^{12)}$ 。本報においても，加速度線形補間を用いて実建物の地震応 答観測記録に基づき加速度計非設置階の応答加速度を推定する。ま た, 免震層および上部構造の層剛性を評価し, 設計值との比較を行う。

\title{
2. 対象建物および計測装置の概要
}

東京工業大学すずかけ台キャンパス（横浜市緑区）には，超高層免 震建物として図 1 に示寸総合研究棟 2 号館（以後 J2 棟）がある。本 建物は, 1 つの建物としては計測点数が多く, また, 平面形状が単純 な矩形であるため, 基礎的な挙動を議論するのに適している ${ }^{3)}$ 。図 2 に，J2 棟の立面図を示す。 J2 棟は 2005 年に竣工した地上 20 階，棟 屋 2 階, 高さ $91.4 \mathrm{~m}$ の鉄骨造超高層免震建物で, 平面形状は 15.8 $\mathrm{m} \times 46.2 \mathrm{~m}$ である。敷地が傾斜地に位置しており， 1 階の半分以上が 周囲の土に埋もれているため, 1 階と 2 階の間に免震層を有する中間 層免震構造が採用されている。上部構造は CFT 柱を用いた鉄骨造, 基礎および 1 階は鉄筋コンクリート造である。また，基礎構造は $\mathrm{N}$ 值 50 以上の土丹層を支持層とする直接基 礎（布基礎）である。上部構造は短手方向 （X 方向）の塔状比が 5 を超える扁平な形 状の建物であるため, X 方向には水平剛性 を高めるために 4 層を 1 ユニットとして架 け渡すメガブレースが設置されている ${ }^{13)}$ 表 1 に設計時における建物の動的特性を示 す ${ }^{13)}$ ○メガブレースの設置により，上部構 造の短辺方向の固有周期は，長辺方向より やや短い程度となっている。なお, 現在は

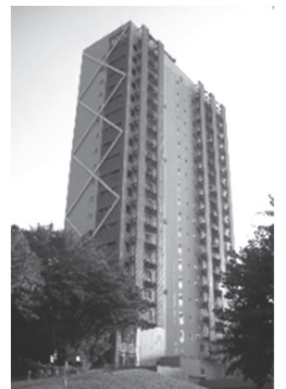

図 $1 \mathrm{~J} 2$ 棟の外観

\footnotetext{
東京工業大学 大学院生

( T 226-8503 神奈川県横浜市緑区長津田町 4259)

東京工業大学末来産業技術研究所 准教授・博士（工学）

JFE エンジニアリング (元東京工業大学) 修士（工学）

東京工業大学 特任教授・Ph.D.
}

Graduate Student, Dept. of Built Environment, Tokyo Institute of Technology

Assoc. Prof., FIRST, Dept. of Built Environment, Tokyo Institute of Technology, Dr. Eng.

JFE Engineering Corporation, M. Eng.

Prof., Tokyo Institute of Technology, Ph.D. 
表 1 設計時における建物の動的特性 ${ }^{13)}$

\begin{tabular}{|c|c|c|c|c|}
\hline & $\begin{array}{c}\text { 免震層 } \\
\text { 固定時 }\end{array}$ & $\begin{array}{c}\text { 微小 } \\
\text { 変形時 }\end{array}$ & $\begin{array}{c}\gamma=50 \% \\
\text { (レベル1相当) }\end{array}$ & $\begin{array}{c}\gamma=150 \% \\
\text { (レベル2相当) }\end{array}$ \\
\hline 短辺方向 $(\mathrm{X})$ & 2.179秒 & 2.869秒 & 3.608 秒 & 4.231 秒 \\
\hline 長辺方向 $(\mathrm{Y})$ & 2.507 秒 & 3.099 秒 & 3.785 秒 & 4.379 秒 \\
\hline
\end{tabular}
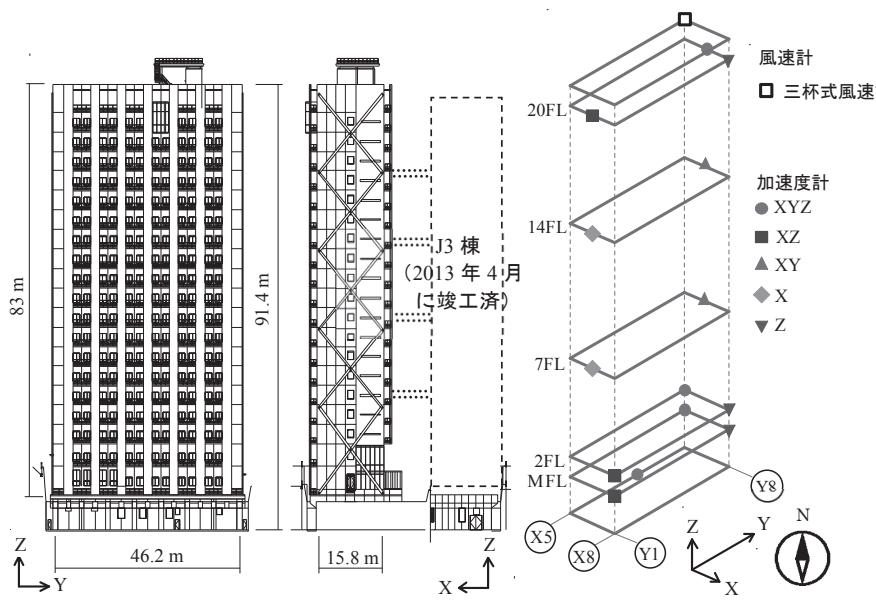

図 2 J2 棟立面図

\section{図 3 加速度計設置位置}

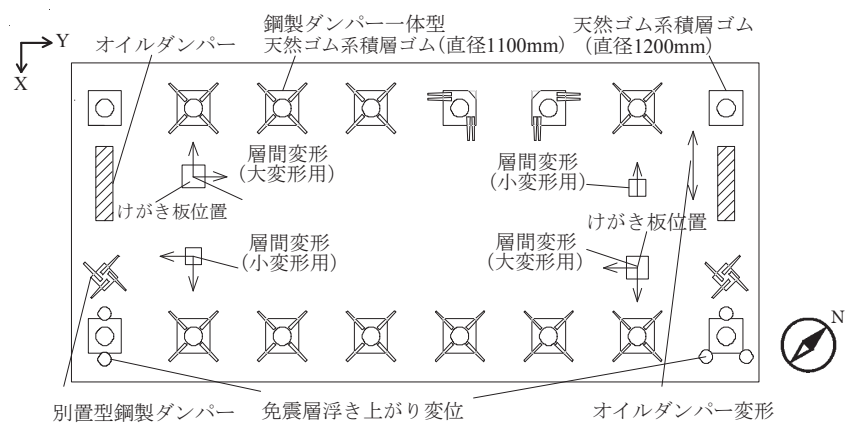

図 4 免震層変位計および免震装置の配置

表 2 観測記録の概要

\begin{tabular}{|c|c|c|c|c|c|c|c|c|}
\hline \multirow[t]{2}{*}{ 年月日 } & \multirow[t]{2}{*}{ 震源地 } & \multirow[t]{2}{*}{ M } & \multicolumn{2}{|c|}{$\begin{array}{c}\text { 最大地動 } \\
\text { 加速度 }\left(\mathrm{cm} / \mathrm{s}^{2}\right)\end{array}$} & \multicolumn{2}{|c|}{$\begin{array}{c}\text { 免震層 } \\
\text { 最大変 } \\
\text { 位 }(\mathrm{cm})\end{array}$} & \multicolumn{2}{|c|}{$\begin{array}{c}\text { せん断ひずみ } \\
(\%)\end{array}$} \\
\hline & & & $X$ & $\mathrm{Y}$ & $X$ & $\mathrm{Y}$ & $\mathrm{X}$ & $\mathrm{Y}$ \\
\hline $11 / 03 / 11$ & 三陸沖（本震） & 9.0 & 50.1 & 67.2 & 6.30 & 9.71 & 28.6 & 44.1 \\
\hline $11 / 03 / 11$ & 茨城県沖（余震） & 7.7 & 21.3 & 26.0 & 3.21 & 6.58 & 14.6 & 29.9 \\
\hline $11 / 03 / 15$ & 静岡県東部 & 6.4 & 14.4 & 9.64 & 0.599 & 0.666 & 2.72 & 3.03 \\
\hline
\end{tabular}

隣に J3 棟が建設され, J2 棟と連結されているが (2013 年 4 月竣工), 静岡県東部地震時（2011 年 3 月 15 日）は $\mathrm{J} 3$ 棟の 2 階床の躯体工事 中であり，J2 棟とは連結されていなかったため，J2 棟を独立した建 物と見なす。図 3 に加速度計の設置位置を, 図 4 に免震層変位計お

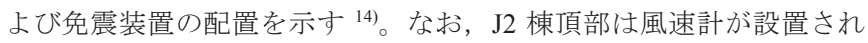
ており, 常時風応答観測を行っている。J2 棟には計 $27 \mathrm{ch}$ の加速度計 (1FL, 免震層床 $(\mathrm{MFL}), 2 \mathrm{FL}, 7 \mathrm{FL}, 14 \mathrm{FL}, 20 \mathrm{FL})$, 免震層には計 $13 \mathrm{ch}$ の変位計が設置されている。加速度計・変位計はそれぞれ $40 \mathrm{~Hz}$ のアナログローパスフィルタを介して $100 \mathrm{~Hz}$ で収録されている。免 震層は直径 $1100 \mathrm{~mm}$ (鋼製ダンパー一体型)，1200 mm の天然ゴム系 積層ゴム（NRB1100, NRB1200）計 16 基, 別置型鋼製ダンパー2 基, オイルダンパー2 基（X方向のみ）から構成されている。なお, 鋼製 ダンパーの降伏変位は $31.7 \mathrm{~mm}$ である。

\section{3. 観測記録の概要 \\ 3. 1 観測記録の処理方法}

$\mathrm{J} 2$ 棟には免震層に変位計が, 上部構造 $(2 \mathrm{FL} ， 7 \mathrm{FL} ， 14 \mathrm{FL}, 20 \mathrm{FL})$ に加速度計が設置されており，検討に用いる観測記録には以下の処 理方法を行った。加速度計・変位計の観測記録を用いる際は, 計測開 始から 100 個のデータの平均值を全体から引き, 初期值の補正を行 っている。加速度記録は同処理を行った後, $30 \mathrm{~Hz}$ より高周波数側を ノイズと判断し， $30 \mathrm{~Hz}$ のローパスフィルターをかけた ${ }^{4)}$

\section{2 地震動の概要}

本報では, 超高層免震建物の観測記録のうち, 振動レベルが異なる 記録である, 三陸沖地震 (本震) (2011 年 3 月 11 日 $14: 46$, M9.0), 茨城県沖地震（余震）（2011 年 3 月 11 日 $15: 15, M 7.7$ ), 静岡県東 部地震（2011 年 3 月 15 日 $22: 28, M 6.4 ）$ 15)を用いて分析を行う。表 2 に地震動の観測記録の概要を示す。なお, せん断ひずみは, 免震層 最大変位を, 免震層に設置されている直径 $1100 \mathrm{~mm}$ (12 基, ゴム層

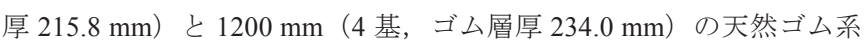
積層ゴムのゴム層厚でそれぞれ除し，その平均值としている。

図 5 に, 検証する地震動の $\mathrm{X}$ 方向および $\mathrm{Y}$ 方向の加速度時刻歴波 形を示す。なお, 図 3 に示すように, 加速度計は北東（NE）側およ び南西（SW）側に設置されているが，本報においては全ての層にお

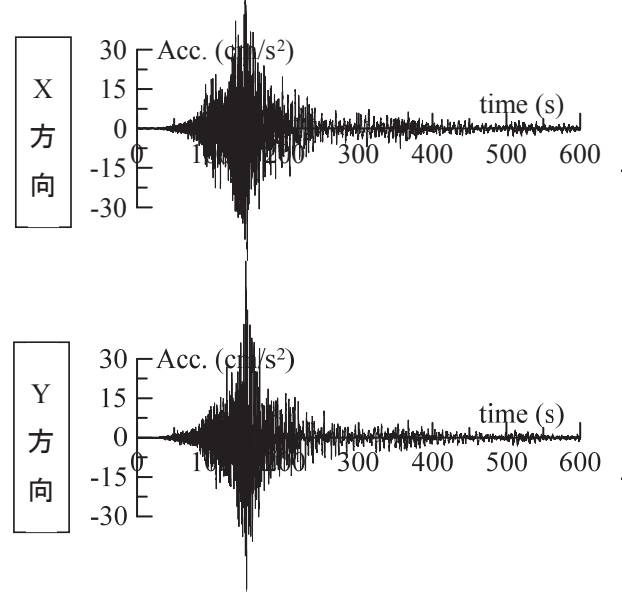

（a）三陸沖地震
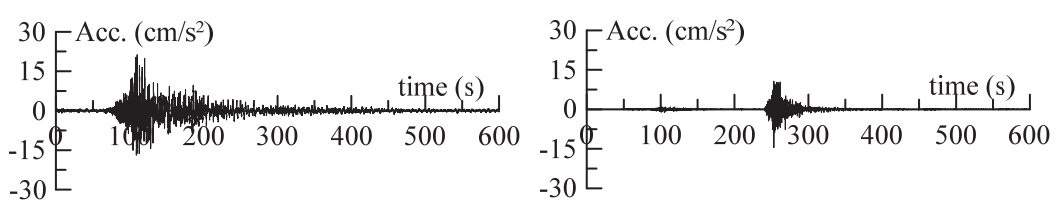

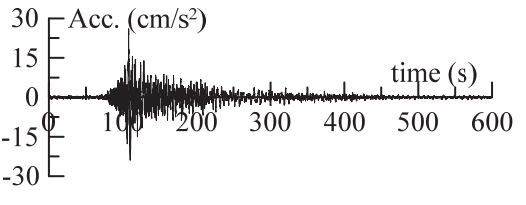

（b）茨城県沖地震

図 5 加速度時刻歴波形

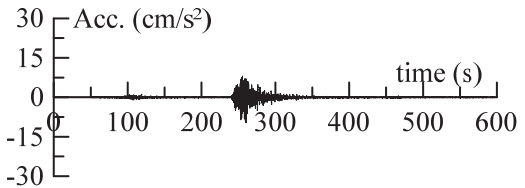

（c）静岡県東部地震 

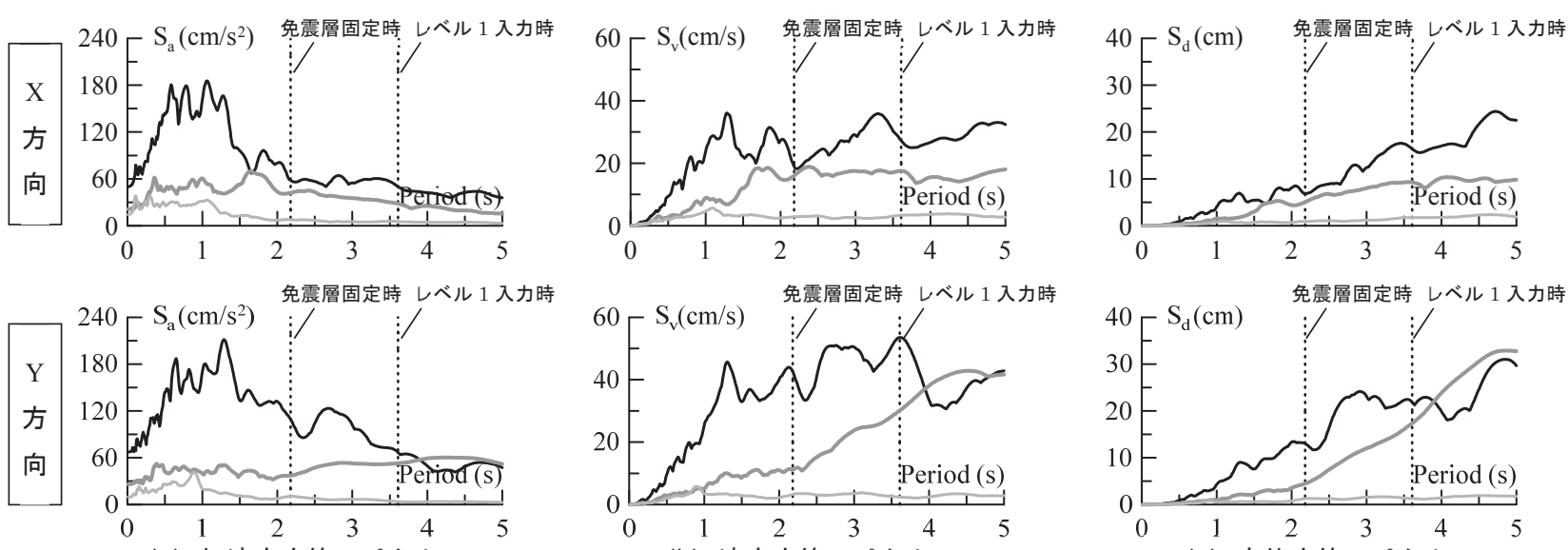

（b）速度応答スペクトル

（a）加速度応答スペクトル

図 6 応答スペクトル $(h=5 \%)$

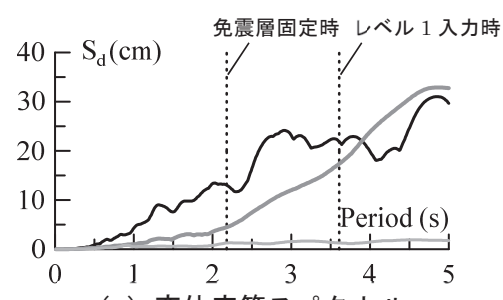

(c) 変位応答スペクトル

いて NE 側の加速度記録のみを使用することとする (4.3 節, 後述)。 また, $\mathrm{J} 2$ 棟の 1 階の半分以上は周囲の土に埋もれており, 1 階は RC 構造のため上階より剛性が高く, 三陸沖地震発生時においてもほと んど変形していなかったため, 本報では免震層床を本建物の基䃈と して考える ${ }^{3)}$ 。

図 6 に減衰定数 $5 \%$ での 3 波の加速度, 速度, 変位の応答スペクト ルを示寸。なお, 図 6 には免震層固定時およびレベル 1 入力時の固 有周期（表 1）を示している。図 6(a)の加速度応答スペクトルをみる と, $\mathrm{X}$ 方向, $\mathrm{Y}$ 方向ともに, 三陸沖地震は周期 0.5 秒から 1.5 秒で 150 $\mathrm{cm} / \mathrm{s}^{2}$ を超える大きな入力であることが確認できる。茨城県沖地震は 周期 0.5 秒から 2 秒で約 $60 \mathrm{~cm} / \mathrm{s}^{2}$ と, 三陸沖地震の加速度応答スペク トルの約 0.4 倍である。静岡県東部地震は, 周期 1 秒で約 $30 \mathrm{~cm} / \mathrm{s}^{2}$ と, 三陸沖地震の約 0.2 倍と, 他の 2 波に比べて低い地震である。また, 茨城県沖地震の Y 方向の全ての応答スペクトルは, 周期 4 秒から 5 秒で三陸沖地震の応答スペクトルよりも大きい值を示すことから, 長周期成分を多く含む地震であることが確認できる。

\section{3 応答記録の概要}

本報で使用する 3 波の加速度応答の最大值を高さ方向にプロット し, 加速度計設置階の北側に設置されている加速度計の $\mathrm{X}$ 方向およ び Y 方向の加速度記録を比較する。図 7 に最大加速度の高さ方向分 布を示す。 $20 \mathrm{FL}$ の最大加速度応答は三陸沖地震で $88.6 \mathrm{~cm} / \mathrm{s}^{2}$ ( $\mathrm{X}$ 方 向), $115.6 \mathrm{~cm} / \mathrm{s}^{2}$ ( $\mathrm{Y}$ 方向), 茨城県沖地震で $50.1 \mathrm{~cm} / \mathrm{s}^{2}$ ( $\mathrm{X}$ 方向), 57.3 $\mathrm{cm} / \mathrm{s}^{2}$ ( $\mathrm{Y}$ 方向), 静岡県東部地震で $14.4 \mathrm{~cm} / \mathrm{s}^{2}$ ( $\mathrm{X}$ 方向), $15.1 \mathrm{~cm} / \mathrm{s}^{2}$ ( $\mathrm{Y}$ 方向）である。図 7 より, 三陸沖地震および茨城県沖地震では全層で $\mathrm{Y}$ 方向が $\mathrm{X}$ 方向の加速度記録よりも大きいことが分かる。静岡県東 (a) 三陸沖地震

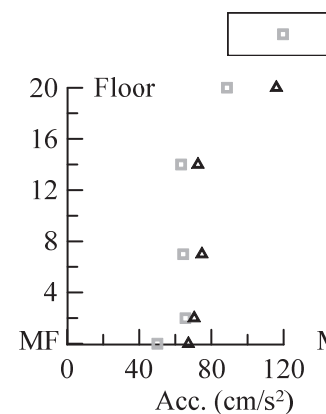

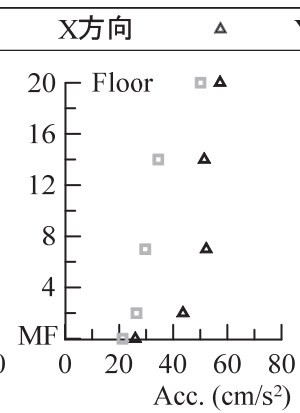

（b）茨城県沖地震

\section{Y方向}

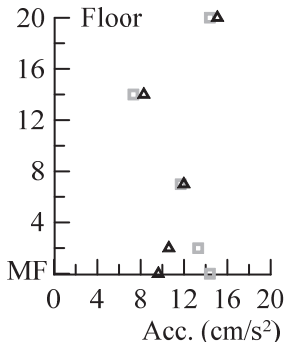

(c) 静岡県東部地震

\section{図 7 加速度最大值高さ方向分布}

部地震の加速度は，7FL，14FL，20FL では Y 方向が X 方向よりも僅 かに大きいが, $2 \mathrm{FL}, \mathrm{MFL}$ では X 方向の方が大きい。また, 上部構 造の加速度は高次モードの影響と考えられる分布となっていること が確認できる。

\section{4. 層剛性の算出}

\section{1 層剛性の算出方法}

本報では, 免震層および上部構造の地震時の建物剛性を把握する ことを目的として, 地震発生時に観測された $\mathrm{J} 2$ 棟の加速度記録を使 用して, 各層の剛性を算出する。各層のせん断力 $Q_{i}(t)(i=\mathrm{M}, 2, \cdots$, 20）は式(1)に示すように, 設計図書に基づく各層の質量 $M_{i}$ と絶対加 速度 $\ddot{X}_{i}(t) \quad(i=\mathrm{M}, 2, \cdots, 20)$ の積の合力で求められる。ただし, 後述するように (4.2 節)，21，22 層の加速度は線形補間により推定 することが出来ないため, 20 層と同じ応答をすると考え, 21,22 層 の質量は2 0 層の質量に組み込むこととする。

$$
Q_{i}(t)=\sum_{j=i}^{20} M_{j} \ddot{X}_{j}(t)
$$

層間変位 $\delta_{i}(t) \quad(i=\mathrm{M}, 2, \cdots, 20)$ については, 上下階の加速度の 差を 2 階積分して算出する(式(2))。加速度 2 階積分より算出する手 法および変位の精度に関しては次節で述べる。

$$
\delta_{i}(t)=\iint\left(\ddot{X}_{i+1}(t)-\ddot{X}_{i}(t)\right) d t
$$

各層の加速度記録より算出した $\delta_{i}-Q_{i}$ の履歴曲線（5 章, 後述）か ら最小二乗法によって層剛性 $K_{i}$ を算出する。

\section{2 加速度線形補間の概要}

2 章で示したように，J2 棟には上部構造（2FL，7FL，14FL，20FL のみ) に加速度計が設置されている。本報では, 限定された層の加速 度記録を用いて, 線形補間により全層の応答加速度を推定し, 層剛性 を算出する。図 8 に示すように, 加速度設置階で計測された上層の 加速度 $\ddot{X}_{u}(t)$ および加速度設置階で計測された下層の加速度 $\ddot{X}_{l}(t)$ を 用いて各層の加速度 $\hat{\ddot{X}}_{i}(t)$ を, 推定する (式(3))。

$$
\hat{\ddot{X}}_{i}(t)=\frac{L_{k l} \ddot{X}_{u}(t)+L_{k u} \ddot{X}_{l}(t)}{L_{k l}+L_{k u}}
$$

ただし $,(u, l)=(7,2),(14,7),(20,14), \quad L_{k u}: u$ 層から $i$ 層まで の距離, $L_{k l}: l$ 層から $i$ 層までの距離 


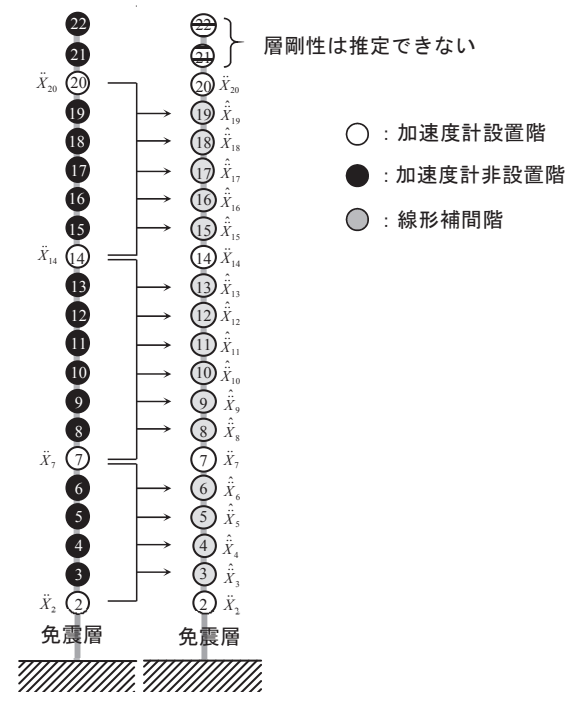

図 8 加速度の線形補間の概要

なお，線形補間後の応答加速度を用いて地震応答時の各層の剛性 を算出する手法の妥当性を確認するために, 3 次元部材モデル 16)を用 いた動的応答解析を行い, 各層の応答加速度を出力して算出した層 剛性 (精解值) と, 線形補間した応答加速度を用いて算出した層剛性 を比較した。その結果, 線形補間により算出した層剛性は, 精解值の $\pm 10 \%$ 以内おさまることを確認している。

\section{3 掘れの検討}

各層の剛性を加速度から算出するため, 本報で使用する地震動に より建物に㧖れが発生するかを確認する必要がある。本章では, 20FL の北側 (X 万方 $(\mathrm{NE})$ ) および南側 $(\mathrm{X}$ 方向 $(\mathrm{SW})$ ) に設置された加 速度計の加速度記録を比較し, 建物の㧖れの検討を行う。図 9 に 3 波 の X 方向（NE）とX 方向（SW）の 20FL の加速度記録のうち, 加速 度記録のピーク時間を含む 10 秒間の加速度応答の時刻歴波形を示す。 図 9 より，20FLのX方向（NE）およびX 方向（SW）の応答加速度 の時刻歴波形は概ね一致している。紙幅の都合によりここでは示さ ないが，MFL，2FL，7FL，14FLの応答加速度の時刻歴波形に関して も同様の結果が得られることを確認している。以上の検討より，本報

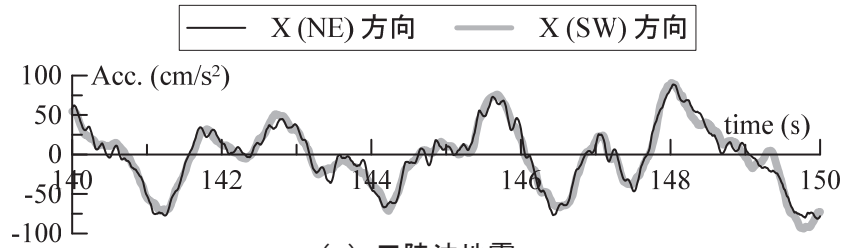

（a）三陸沖地震

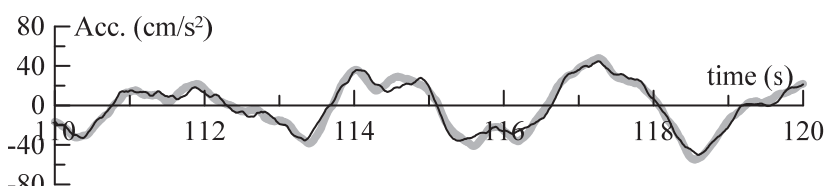

（b）茨城県沖地震

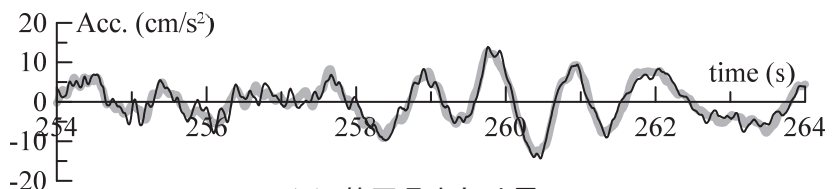

（c）静岡県東部地震

図 9 応答加速度の時刻歴波形（20FL）

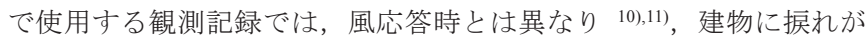
ほとんど発生していないことを確認したため，以降では建物北側の 加速度記録のみを使用して，各層の剛性を算出する。

\section{4 加速度 2 階積分の精度の確認}

$\mathrm{J} 2$ 棟の免震層には加速度計だけでなく, 大変形用と小変形用の変 位計が北側と南側にそれぞれ設置されている（図 4)。本章では加速 度 2 階積分の精度を確認するために, $2 \mathrm{FL}$ と MFL の加速度記録の差 から 2 階積分より算出した免震層変位と, 免震層変位計の観測記録 を比較する。4 章より，本報で使用する 3 波の地震動では建物に㧖れ がほとんど発生しないことを確認したため, 免震層の変位計は変位 計の容量および分解能 ${ }^{13)}$ より, 北側に設置されている小変形用を使 用する。なお，文献 3)では，三陸沖地震において，加速度記録に 0.1 $\mathrm{Hz}$ のハイパスフィルターをかけ，加速度記録の長周期成分を除くこ とで, 積分の精度を得ることを確認している。茨城県沖地震および静 岡県東部地震においても $0.1 \mathrm{~Hz}$ のハイパスフィルターが適している ことを確認するため, 本報においても $0.1 \mathrm{~Hz}$ のハイパスフィルター をかけ，周波数領域での積分手法を用いる。図 10 に加速度計および 免震層変位計から得られた時刻歴波形の比較を示す。なお，図示する 時刻歷波形は，3波それぞれの変位記録のピーク時間を含む 20 秒間 である。図 10 より, 加速度計および免震層変位計より算出した時刻 歴波形は概小一致していることから, 加速度 2 階積分の精度が確認 された。

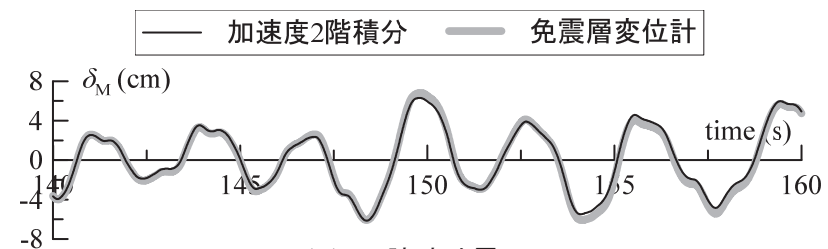

（a）三陸沖地震

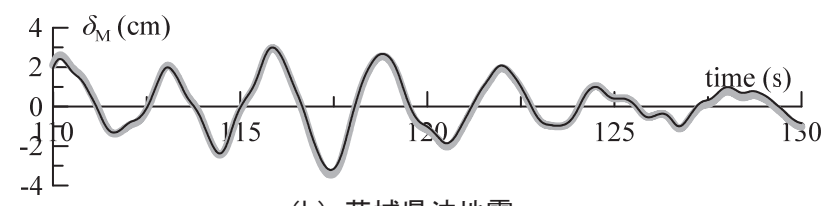

（b）茨城県沖地震

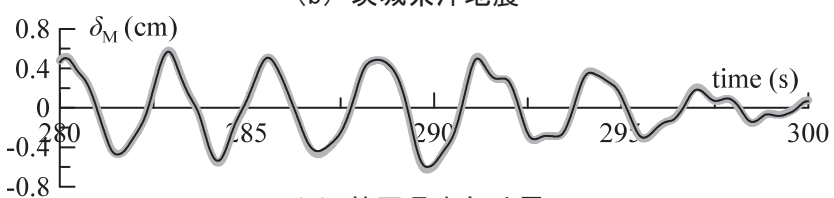

(c) 静岡県東部地震

図 10 加速度計および免震層変位計より算出した変位の時刻歴波形

\section{5. 層剛性の算出結果}

\section{1 設計値と観測記録より算出した層剛性の比較}

本節では, 異なる振動レベルの地震波において, 免震層および上部 構造の層剛性が設計值に対してどのような值を示すのかを分析する 図 11 に免震層の $\delta_{\mathrm{M}}-Q_{\mathrm{M}}$ の履歴曲線および最小二乗法より算出した 近似曲線 $K_{i}$ と設計值との比較を示寸。なお, 三陸沖地震および茨城 県沖地震は, $\mathrm{X}$ 方向, Y 方向ともに鋼製ダンパーの降伏変位を超える 振幅を確認したため, 降伏変位以降のデータを全て除き, 弾性範囲で の記録から剛性を算出している。図 11 より，全ての観測記録におい て免震層の層剛性は設計值と概初等しいことが分かる。図 12〜14に 
上部構造 $(5,10,15$ 層）の履歴曲線および最小二乗法より算出した 近似曲線 $K_{i}$ と設計值との比較を示す。図 12〜14より, 全ての観測記 録において上部構造の剛性は設計值より高いことが確認できる。

\section{2 最大層間変位と層剛性}

図 15 に，免震層および上部構造（5，10，15 層）における最大層 間変位と, 設計值と観測記録より算出した層剛性の比較 $\left(K_{i} /{ }_{D} K_{i}\right)$ を示す。なお，三陸沖地震および茨城県沖地震の免震層における最大 層間変位は, $\mathrm{X}$ 方向, $\mathrm{Y}$ 方向ともに鋼製ダンパーの弾性限でプロット している。図 15 より，免震層の層剛性は，全ての観測記録において 設計值の約 $\pm 15 \%$ 以内であり, 設計值に近い值を示した。上部構造で は振幅が大きくなると剛性が低くなり，上部構造の振幅依存性が確 認できた。また，振幅が大きくなるほど設計值に近づくことを確認し た。
6. まとめ

本報では，超高層免震建物の地震時における免震層および上部構 造の層剛性の振動レベルによる違いを把握することを目的として, 東京工業大学にある超高層免震建物の $\mathrm{J} 2$ 棟で観測された地震応答観 測記録のうち, 振動レベルが異なる記録である, 三陸沖地震, 茨城県 沖地震，静岡県東部地震を用いて分析を行った。その結果，観測記録 に基づく免震層の層剛性は，全ての観測記録において設計值の約士 15\%以内であり，設計值に近い值を示した。振幅が大きくなると剛性 が低くなり，上部構造の振幅依存性が確認できた。また，振幅が大き くなるほど設計值に近づくことを確認した。

\section{謝辞}

本研究で用いた J2 棟の観測データは, 東京工業大学 GCOE プロラ ムから提供して頂いたものであります。厚く御礼申し上げます。

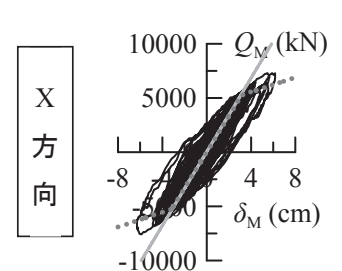

(a) 三陸沖地震

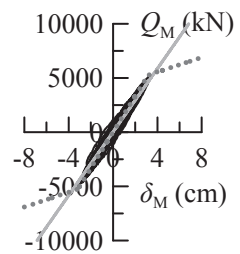

(b) 茨城県沖地震

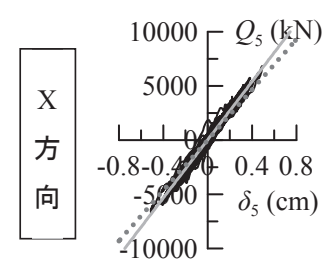

(a) 5 層

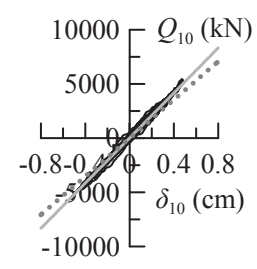

(b) 10 層

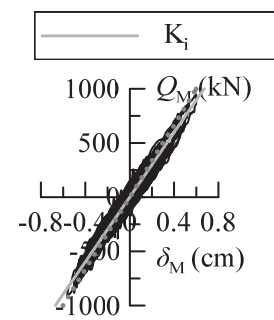

(c) 静岡県東部地震

\section{……... 設計値}

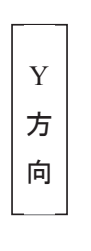

図 11 免震層の履歴曲線の比較

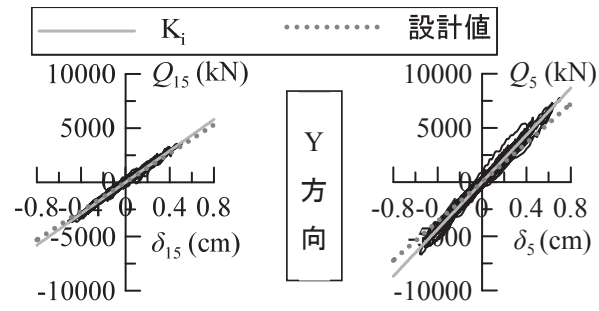

(c) 15層

(d) 5 層

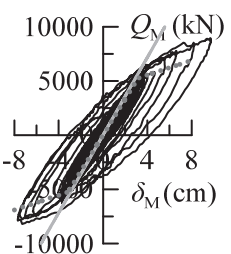

(d) 三陸沖地震

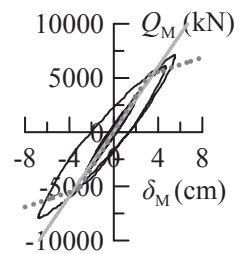

(e) 茨城県沖地震

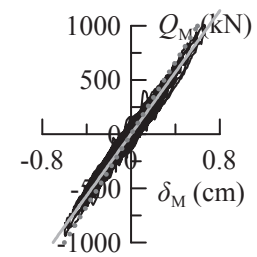

(f) 静岡県東部地震

図 12 上部構造の履歴曲線の比較 (三陸沖地震)

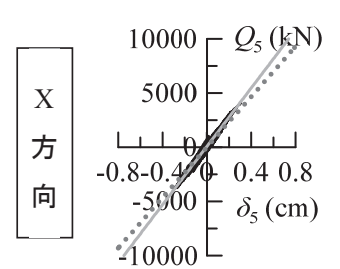

(a) 5 層

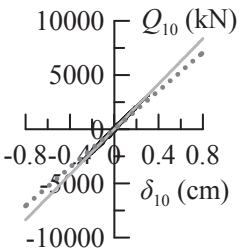

(b) 10 層

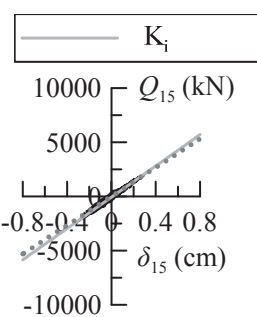

(c) 15 層

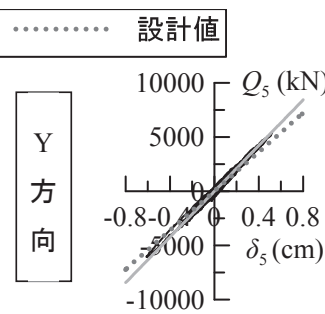

(d) 5 層

図 13 上部構造の履歴曲線の比較 (茨城県沖地震)

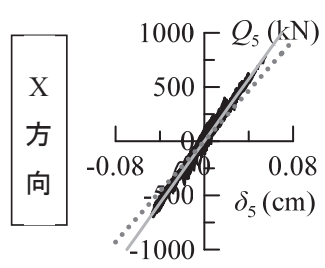

(a) 5 層

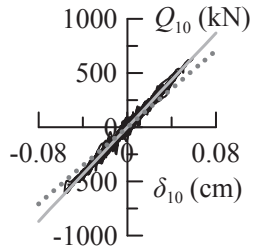

(b) 10 層

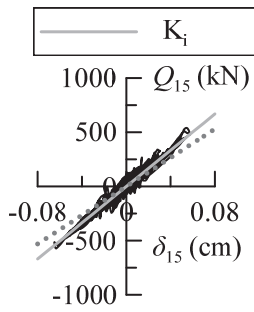

(c) 15層

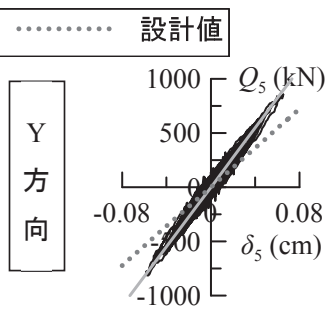

(d) 5 層

図 14 上部構造の履歴曲線の比較（静岡県東部地震）

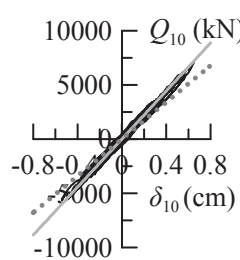

(e) 10 層

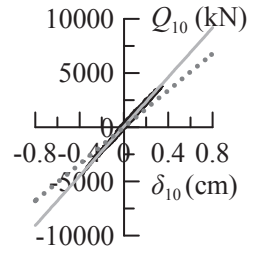

(e) 10 層

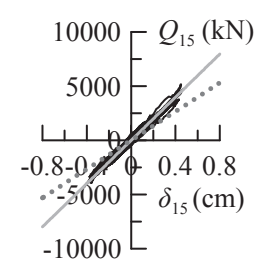

(f) 15 層

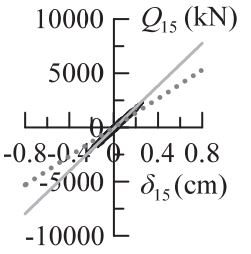

(f) 15 層

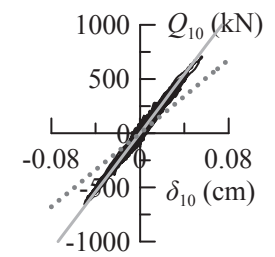

(e) 10 層

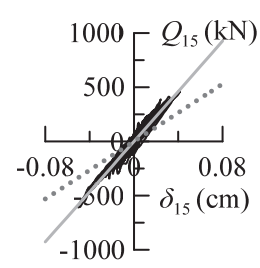

（f） 15 層 

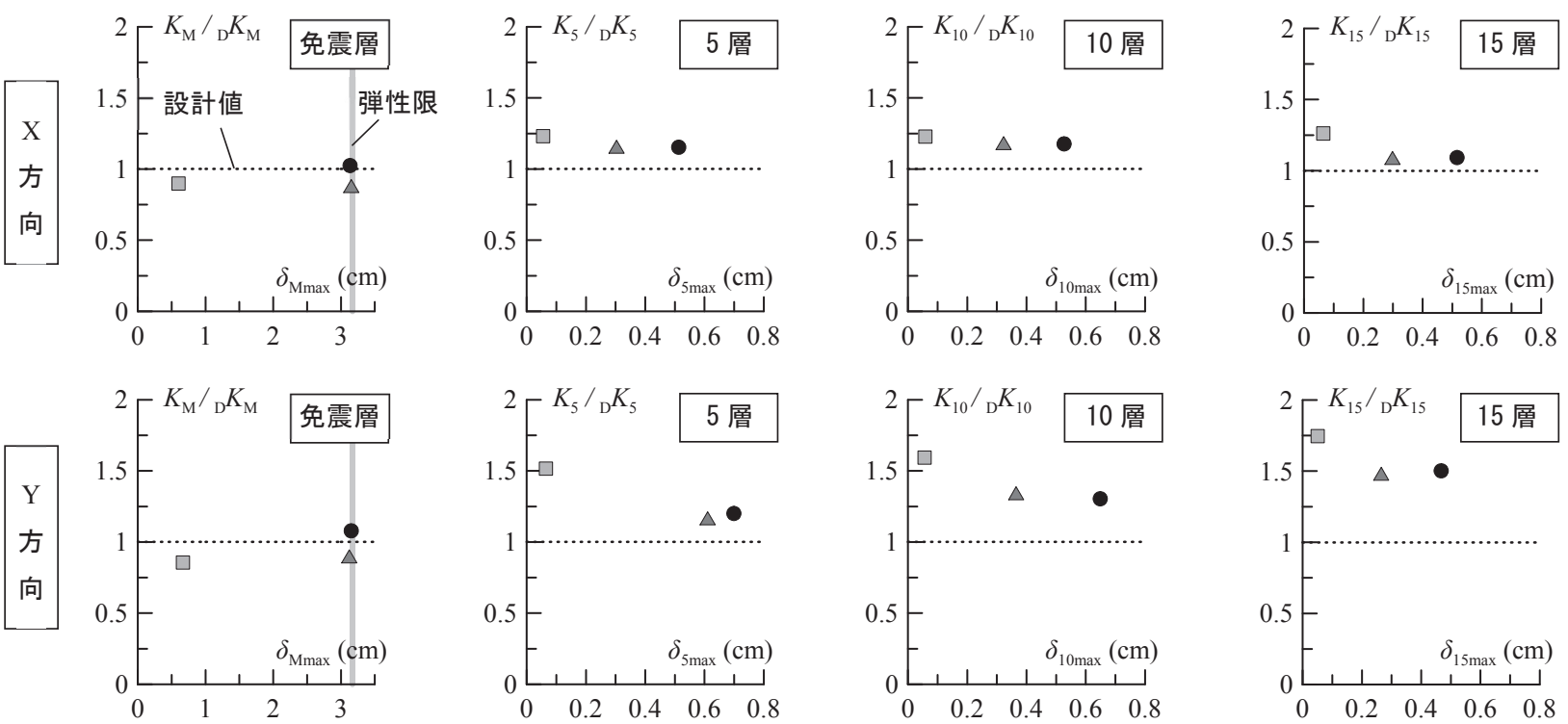

参考文献

1) 日本免震構造協会運営委員会 : 2014年度免震制振建物データ集積結果, MENSHIN, No.89, pp.20-25, 2015.8

2) 天埜貴仁，高橋武宏，福和伸夫，護雅史，飛田潤 : 継続的な地震観測及 び微動計測に基づく高層免震建物の建設時における振動特性の変化, 日 本建築学会構造系論文集, 第79巻, pp.721-730, 2014.6

3) 松田和浩, 笠井和彦: 東北地方太平洋沖地震における観測記録を用いた 超高層免震建物の動的挙動に関寸る研究, 日本建築学会構造系論文集, 第79巻 第704号, pp.1445-1455, 2014.10

4) 佐藤大樹, 鈴木勇人, 田村哲郎, 普後良之, 中村修, 笠井和彦, 北村 春幸 : 超高層免震建物の観測記録に基づく風応答の分析, 第 22 回風工 学シンポジウム, pp.251-256, 2012

5) 吉江慶祐, 村上智一, 佐藤大樹, 田村哲郎, 普後良之, 佐藤利昭, 北村 春幸，笠井和彦 : 風応答観測記録に基づく超高層免震建物の免震ダンパ 一の疲労損傷評価（その1 免震層変位波形および疲労損傷度の分析）， 日本建築学会大会学術講演便概集（九州），pp.397-400，2016.8

6) 村上智一, 佐藤大樹, 吉江慶祐, 田村哲郎, 普後良之, 佐藤利昭, 北村 春幸，笠井和彦: 風応答観測記録に基づく超高層免震建物の免震ダンパ 一の疲労損傷評価（その2 10 分毎のデータを用いた疲労損傷評価手法 の提案），日本建築学会大会学術講演便概集（九州），pp.401-404，2016.8

7) 村上智一, 佐藤大樹, 田村哲郎, 普後良之, 吉江慶祐, 笠井和彦, 佐藤 利昭，北村春幸 : 強風時の観測記録に基づく超高層免震建物の実挙動の 分析, 構造工学論文集, Vol.62B, pp.329-337, 2016.3

8) 佐藤大樹, 大木洋司, 盛川仁, 山田哲, 坂田弘安, 山中浩明, 笠井和彦, 和田章，北村春幸 : 観測記録に基づく超高層免震建物の応答特性に関す る研究 (その1 建物概要および地震応答特性), 日本建築学会大会学術 講演便概集，pp.309-310，2008.9

9）中井亜里沙，佐藤大樹，村上智一，田村哲郎，普後良之，吉江慶祐，笠 井和彦: 強風時の観測記録に基づく超高層免震建物の捩れ振動特性の分 析一その1 加速度の捩れ成分および固有振動数の分析, 日本建築学会 関東支部研究報告集(CD-ROM)，2038，pp.413-416，2017.3

10）中井亜里沙，佐藤大樹，村上智一，田村哲郎，普後良之，吉江慶祐，笠 井和彦: 強風時の観測記録に基づく超高層免震建物の捩れ振動特性の分 析一その2 㧖れ成分の加速度時刻歴波形による据れ回転中心位置の推 定, 日本建築学会関東支部研究報告集(CD-ROM), 2039, pp.417-420, 2017.3

11) 中井亜里沙，佐藤大樹，村上智一：地震応答観測記録に基づく超高層免 震建物の免震層および上部構造の剛性の分析, 日本地震工学会・大会, 第12回年次大会梗概集，P3-26，2016.9

12）久保田航平，金澤健司，吉澤伊織，北村春幸：計測範囲を超過した地震 応答データに対する建築物のシステム同定適用 その2 加速度補完法と 等価せん断力縮約法の提案, 2012年度日本建築学会関東支部研究報告集 I , pp.413-416，2013.3
13) 菊地岳志, 藤森智, 竹内徹, 和田章 : メガブレースを用いた超高層免震 鋼構造建築物の設計，日本建築学会技術報告集，第22号，pp.217-222， 2005.12

14）大木洋司，山下忠道，盛川仁，山田哲，坂田弘安，山中浩明，笠井和彦， 和田章: 超高層免震建物の長期観測システム構築に関する具体的取り組 み，日本建築学会技術報告集，第21号，pp.73-77，2005.6

15) 気象庁：報道発表資料，http://www.jma.go.jp/jma/press/hodo.html（2017年 5 月参照)

16) 中井亜里沙，佐藤大樹，村上智一，普後良之，田村哲郎：3次元モデルを 用いた超高層免震建物の弾塑性風応答解析, 日本建築学会大会学術講演 梗概集，B-2，pp.121-122，2017.8

\section{附録}

3次元部材モデル16)を用いて，静的解析結果（以下， ${ }_{\mathrm{S}} K_{i}$ ）と4.1節 より求めた層剛性（以下， $K_{i}$ ) を比較する。附図1(a)，(b)に，X方向， Y方向における $K_{\mathrm{S}} K_{i}$ および $K_{i}$ と，それらの比率 $\left(K_{i} /{ }_{\mathrm{S}} K_{i}\right)$ をそれぞ れ示す。附図1より，免震層の $K_{i}$ は ${ }_{\mathrm{S}} K_{i}$ と概ね一致することが確認で きる。上部構造のX方向における 16 層以下の $K_{i}$ は, ${ }_{\mathrm{S}} K_{i}$ と良い值を示 すが，16層よりも上層になるにつれて誤差が大きくなり，最上層で約 45\%剛性を小さく評価することが確認できる。Y方向における18層以 下の $K_{i}$ は， ${ }_{\mathrm{S}} K_{i}$ と良い值を示すが 18 層よりも上層になるにつれて䛊 差が大きくなり, 最上層で約 $20 \%$ 剛性を小さく評価することが確認で きる。以上より, X方向では16層以下, Y方向では18層以下において, 静的解析と動的解析の剛性評価が良い対応を示すことを確認した。

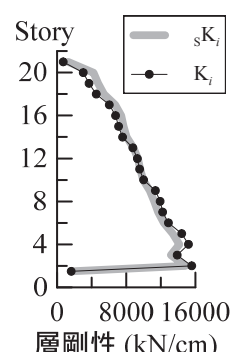

層剛性 $(\mathrm{kN} / \mathrm{cm})$

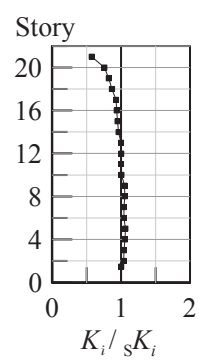

(a) $\mathrm{X}$ 方向

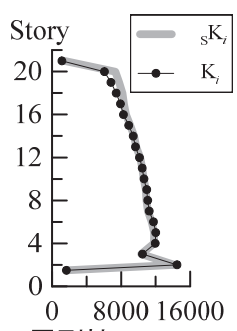

層剛性 $(\mathrm{kN} / \mathrm{cm})$

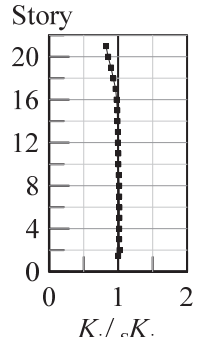

(b) $Y$ 方向
附図 1 静的解析および動的解析による層剛性と比率

[2017 年 10 月 4 日原稿受理 2017 年 11 月 14 日採用決定］ 